\title{
HUBUNGAN PERSEPSI SISWA DALAM PENGELOLAAN KELAS DENGAN KEDISIPLINAN PADA SISWA SMK PABAKU
}

\author{
Liana Mailani
}

Fakultas Psikologi dan Pendidikan

Universitas Al azhar Indonesia

Komplek Masjid Agung Al Azhar, Jakarta, 12110

Abstract---This study aims to determine the correlation between students' perceptions of classroom management and students' discipline of SMK Pabaku. The hypothesis of this study is that there is a positive correlation between students' perceptions of classroom management and their discipline. It is assummed that the more positive student perceptions of classroom management is, the higher discipline will they be. Conversely, the more negative their perception toward class management, the less discipline will they be. The subjects of this research were 155 high school students of SMK Pabaku. Samples were derived by using simple random sampling technique. Data were obtained from the Discipline Scale and Scale Student Perceptions toward Classroom Management. The calculation is done by means of testing requirements analysis (assumption testing) that consists of a test for normality of distribution and relationships linearity test. Data were analysed by applying formula of product moment correlation through SPSS 20 for Windows. Results of data analysis showed that a correlation coefficient was 0.605 with $p$ value of 0.000 ( $p$ <0.05). It shows there is a positive correlation between students' perceptions of classroom management with discipline. The result of this study indicates that the contributions of the students' perceptions of classroom management to discipline are 59.1 percent, and the rest 49.9 percent is influenced by other factors not examined. From these results, it can be concluded 
that the hypothesis stating that there is a positive relationship between students' perceptions of classroom management with discipline, can be accepted.

Keywords: discipline; perception

\begin{abstract}
Abstrak---Penelitian ini bertujuan untuk menentukan korelasi antara persepsi siswa tentang manajemen kelas dan disiplin siswa SMK Pabaku. Hipotesis dari penelitian ini adalah bahwa ada korelasi positif antara persepsi siswa tentang manajemen kelas dan disiplin mereka. Hal ini diasumsikan bahwa persepsi siswa yang lebih positif dari manajemen kelas adalah, disiplin yang lebih tinggi akan mereka. Sebaliknya, semakin negatif persepsi mereka terhadap manajemen kelas, semakin sedikit disiplin mereka. Mata pelajaran penelitian ini adalah 155 siswa SMA SMK Pabaku. Sampel diperoleh dengan menggunakan teknik random sampling sederhana. Data diperoleh dari Skala Disiplin dan Skala Persepsi Siswa terhadap Manajemen Kelas. Perhitungan dilakukan dengan cara pengujian persyaratan analisis (asumsi pengujian) yang terdiri dari tes untuk normalitas distribusi dan hubungan linearitas tes. Data dianalisis dengan menerapkan formula korelasi produk moment melalui SPSS 20 untuk Windows. Hasil analisis data menunjukkan bahwa koefisien korelasi adalah 0,605 dengan nilai p 0,000 (p \&lt;0,05). Ini menunjukkan ada korelasi positif antara persepsi siswa tentang manajemen kelas dengan disiplin. Hasil penelitian ini menunjukkan bahwa kontribusi persepsi siswa terhadap manajemen ruang kelas untuk disiplin adalah 59,1 persen, dan sisanya 49,9 persen dipengaruhi oleh faktor-faktor lain yang tidak diperiksa. Dari hasil ini, dapat disimpulkan bahwa hipotesis yang menyatakan bahwa ada hubungan hubungan positif antara persepsi siswa tentang manajemen kelas dengan disiplin, dapat diterima.
\end{abstract}

Keywords: Disiplin; Persepsi

\title{
PENDAHULUAN
}

Tingginya tingkat persaingan di dunia dewasa ini menuntut individu untuk dapat unggul dan tidak kalah bersaing. Selain kompetensi banyak hal yang menjadi ukuran keberhasilan 
individu salah satunya adalah moral yang diharapkan dapat berkembang pada individu, Menurut Santrock (2008) perkembangan moral ialah perubahan penalaran, dan perilaku yang menjadi standar mengenai benar dan salah. Perkembangan moral memiliki dimensi intrapersonal dimana didalamnya ada interaksi sosial dan dimensi interpersonal yang dapat ikut berperan dalam interaksi sosial konflik. individu yang mampu menjalankan perannya sesuai dengan tugas perkembangannya.

Individu yang dalam masa perkembangan seperti remaja yang masih duduk di sekolah SMK sederajat, dalam mengikuti proses belajar mengajar di sekolahnya, tidak akan lepas dari peraturan dan tata tertib yang berlaku. Peraturan, tata tertib, dan berbagai ketentuan berupaya mengatur perilaku remaja, kepatuhan dan ketaatan ter rhadap aturan dan tata tertib pada remaja disekolah, kadangkala diterapkan pemberikan hukuman (sanksi) sebagai konsekuensi dari pelanggaran terhadap aturan, meski kadangkala menjadi kontroversi, tetapi hukuman (sanksi) tetap diberlakukan karena ancaman hukuman dan sanksi dianggap dapat memberikan dorongan dan kekuatan bagi sebagian remaja untuk menaati dan mematuhinya.

Kesadaran akan pentingnya norma, aturan, kepatuhan dan ketaatan merupakan prasyarat kesuksesan Individu tumbuhnya rasa aman, tenang, tentram, tertib dan teratur, hal ini di dukung oleh Suryabrata (2006) dengan meningkat pengetahuan dan peradaban manusia maka semakin tinggi pula tingkat kedisiplinan manusia, tetapi kenyataannya sekarang justru kemerosotan kedisiplinan yang sangat drastis, kondisi ini disebabkan karena pengetahuan yang tinggi tidak dibarengi dengan pendidikan moral yang memadai, hal ini terlihat jelas di lingkungan sekolah yang mengalami peningkatan ketidakdisiplinan di kalangan siswa seperti keterlambatan, siswa yang sering membolos, perkelahian antar pelajar (tawuran) yang terus terjadi akhir-akhir ini, salah satunya adalah tawuran. Permasalahan-permasalahan yang sering muncul seperti tawuran, bolos sekolah, malas belajar dan lainnya harus dapat diatasi dengan sangat baik salah satunya dengan menerapkan kedisiplinan.

Kedisiplinan adalah peraturan yang diberlakukan di sekolah untuk memelihara perilaku remaja supaya tidak terjadi penyimpangan dan mendorong remaja berperilaku sesuai dengan 
norma yang diterapkan di sekolah, peraturan dan tata tertib yang berlaku di sekolah agar dapat dipatuhi seperti aturan tentang standar berpakaian, tidak pernah telat, selalu tepat waktu mengumpulkan tugas dan tata cara belajar yang baik. Penerapan kedisiplinan secara positif memberi dukungan lingkungan yang tenang dan tertib bagi proses pembelajaran disekolah dan orang tua senantiasa berharap anak-anak remaja mereka diajari dengan norma-norma, nilai kehidupan dan disiplin ,sehingga anak-anak remaja tersebut dapat menjadi individu yang tertib, teratur dan disiplin karena kedisiplinan merupakan jalan bagi remaja untuk sukses dalam belajar dan kelak ketika bekerja. Di lingkungan sekolah kedisiplinan memang diajarkan sehingga itu menjadi sebagian aturan yang selalu diterapkan di sekolah menurut Savage (2010) kedisiplinan dapat diartikan sebagai serangkaian tindakan yang dihubungkan dengan perkembangan pengendaliaan diri, tanggung jawab dan karakteristik diri, jadi dapat dinyatakan lebih lanjut bahwa kedisiplinan bukan hanya sekedar rasa tanggung jawab terhadap perilaku yang tidak baik tetapi lebih ke arah pengendalian diri.

Para siswa disekolah memiliki persepsi, di mana persepsi merupakan proses saat kita mengorganisasikan dan menafsirkan pola stimulus dalam lingkungan (Atkinson,dkk 2002), persepsi terjadi setelah melihat, mendengar, ataupun merasakan sesuatu, dan proses inilah yang terjadi pada persepsi siswa terhadap pengelolaan kelas, di mana siswa membuat persepsi mengenai pengelolaan kelas yang berkaitan dengan peranan guru dikelas yang ditangkap oleh pancaindera siswa, seperti berkonsentrasi saat belajar, tidak ribut dikelas, dan lain-lain, untuk itu respek atau hormat siswa terhadap guru sangat penting dalam pengelolaan kelas ( dalam Djiwandono, 2006).

Seorang guru yang efektif adalah guru yang berkoordinasi dan menyusun kegiatan untuk menemukan tujuan dan sasaran untuk siswanya dan menjadi harapan orang tua dan masyarakat supaya anak-anak mereka dapat mencapai tujuan belajar untuk masa depan. Guru harus mampu menciptakan lingkungan pembelajaran yang efektif dengan melibatkan pengorganisasian kegiatan di ruang kelas, pengajaran, dan penggunaan waktu yang efektif, menciptakan lingkungan pembelajaran yang bahagia dan produktif. Pengelolaan kelas sangat penting kedudukannya karena pengelolaan kelas yang baik bisa mengurangi ketidakdisiplinan siswa 
(Slavin, 2011). Penciptaan lingkungan pembelajaran yang efektif adalah persoalan mengetahui beberapa teknik yang dapat dipelajari dan diterapkan setiap guru, namun meskipun pengelolaan kelas berkedudukan penting pada kenyataannya banyak hal tentang pengelolaan kelas yang diabaikan oleh guru sehingga menimbulkan persepsi yang negatif terhadap proses belajar yang menurunkan kedisiplinan murid, dan biasanya orientasi permasalahan hanya pada persoalan kurang memadainya sarana dan prasarana belajar mengajar.

Padahal sebenarnya terdapat kemungkinan besar bahwa keadaan tersebut disebabkan oleh ketidakmampuan seorang guru dalam mengelola kelas sehingga mengakibatkan menurunnya kedisiplinan di kelas tersebut, agar dapat meningkatnya kedisiplinan, dapat diwujudkan dengan pengelolaan kelas yang efektif. Guru sebagai manajer yang sukses merupakan guru yang bisa memahami masalah akademik dan bertindak profesional, seperti mengerti motif siswa, kepribadiaan, kemampuan, gaya berpikir dan belajar, serta tingkah laku sosial siswanya (Djiwandono, 2006), sehingga timbulnya hubungan yang baik antara guru dan siswa.

Bertitik tolak dari latar belakang penelitian, peneliti tertarik untuk melakukan penelitian tentang Hubungan persepsi siswa dalam mengelola kelas dengan kedisiplinan pada siswa SMK Pabaku

\section{KERANGKA TEORITIS}

Penelitian ini berpijak dari suatu pemikiran bahwa ada Hubungan persepsi siswa dalam mengelola kelas dengan kedisiplinan pada siswa SMK Pabaku.

\section{A. Kedisiplinan}

Menurut Savage (2010) kedisiplinan dapat diartikan sebagai tindakan yang dihubungkan dengan perkembangan dari pengendalian diri, tanggung jawab, dan karakteristik diri, jadi lebih lanjut dinyatakan bahwa disiplin bukan hanya sekedar tanggung jawab terhadap tingkah laku yang tidak baik dalam mengantarkan kurikulum secara efisien, tetapi lebih diarahkan pada pengembangan pada pengendalian diri. 
Menurut Ekosiswoyo dan Rachman (2000), faktor-faktor yang mempengaruhi kedisiplinan, antara lain:

a. Sekolah:

1) Tipe kepemimpinan guru atau sekolah yang otoriter yang senantiasa mendiktekan kehendaknya tanpa memperhatikan kedaulatan siswa. Perbuatan seperti itu mengakibatkan siswa menjadi berpura-pura patuh, apatis atau sebaliknya. Hal itu akan menjadikan siswa agresif, yaitu ingin berontak terhadap kekangan dan perlakuan yang tidak manusiawi yang mereka terima.

2) Guru yang membiarkan siswa berbuat salah, lebih mementingkan mata pelajaran daripada siswanya.

3) Lingkungan sekolah seperti: hari-hari pertama dan hari-hari akhir sekolah (akan libur atau sesudah libur), pergantian pelajaran, pergantian guru, jadwal yang kaku atau jadwal aktivitas sekolah yang kurang cermat, suasana yang gaduh, dan lain-lain.

b. Keluarga

1) Lingkungan rumah atau keluarga, seperti kurang perhatian, ketidak teraturan, pertengkaran, masa bodoh, tekanan, dan sibuk urusannya masing-masing.

2) Lingkungan atau situasi tempat tinggal, seperti lingkungan kriminal, lingkungan bising, dan lingkungan minuman keras.

Menurut Crow dan Crow (dalam Tulus, 2004) kedisiplinan dapat dikategorikan ke dalam 3 (tiga) aspek yang terdiri dari :

a. Kesadaran, yaitu bentuk sikap yang menunjukkan kepekaan terhadap stimuli yang berupa objek, situasi dan masalah yang dimanifestasikan dalam bentuk kerelaan dalam mentaati peraturan serta sadar akan tugas dan tanggung jawab tanpa paksaan.

b. Pemahaman, adalah suatu kemampuan untuk memisahkan dan memberikan batasan agar dasar pengertian yang menuntut adanya kemampuan untuk mengembangkan antara pengalaman yang lalu dan sikap yang berani dalam menyelesaikan atau menanggulangi hambatan-hambatan pemahaman didasarkan atas fakta yang kemudian memerlukan proses 
evaluasi dan klasifikasi sehingga pengorganisasian dalam penentuan masalah serta pemecahan didapatkan secara akurat.

c. Keterampilan, merupakan bentuk kecekatan, kemahiran, kebiasaan yang dimiliki seseorang sebagai hasil latihan, disebut sebagai suatu bentuk latihan karena keterampilan untuk menekankan pada proses belajar, gerak atau perbuatan motorik.

\section{B. Persepsi Siswa Terhadap Pengelolaan Kelas}

Persepsi merupakan cara kita mengintregasikan sensasi ke dalam stimulus suatu objek dan selanjutnya digunakan untuk mengenal dunia dengan menggunakan alat indera (Atkinson, dkk, 2002), dengan kata lain persepsi merupakan kesan pertama yang muncul dan mempengaruhi proses pembelajaran terhadap suatu kondisi selanjutnya. Menurut Chaplin (2008) persepsi adalah proses di mana individu mengorganisasikan, dan menafsirkan pada stimulus lingkungan sekitarnya.

Berdasarkan penelitian Edmund, Emmer, dan Carolyn Evertson (dalam Djiwandono, 2006), pengelolaan kelas didefinisikan sebagai tingkah laku guru yang dapat menghasilkan prestasi siswa yang tinggi karena keterlibatan siswa di kelas, tingkah laku siswa yang tidak banyak mengganggu kegiatan guru dan siswa lain dan menggunakan waktu yang efisien dalam proses belajar mengajar. Apabila persepsi siswa terhadap pengelolaan kelas negatif maka akan terjadi permasalahan di dalam kelas seperti keributan, perkelahian dan kelalian dalam melaksanakan tugas karena guru dianggap tidak kompeten, tidak adil dalam meyingkapi kesalahan yang dilakukan oleh siwa di kelas akibatnya siswa akan sengaja melakukan pelanggaran di dalam kelas sehingga berpengaruh terhadap kedisiplinan di dalamnya, sebaliknya jika siswa memiliki persepsi yang positif terhadap pengelolaan kelas maka akan tercipta suasana belajar dikelas yang nyaman dan aman sehingga proses belajar bisa maksimal (Djiwandono, 2006).

Menurut Ormrod (2011) pengelolaan kelas yang efektif memerlukan peraturan dan prosedur tertentu di awal pembelajaran, dalam hal ini persepsi siswa memegang peranan penting 
sebab bila persepsi siswa terhadap peraturan itu mudah dipahami dan dijalankan karena cukup sederhana dan hanya beberapa saja maka siswa akan melaksanakan peraturan tersebut sehingga kondisi kelas menjadi nyaman dan aman, sebaliknya bila persepsi siswa terhadap peraturan itu dianggap terlalu banyak maka siswa akan merasakan kebosanan dan kejenuhan sehingga suasana kelas yang efektif tidak dapat tercipta dengan baik.

Menurut (Djiwandono, 2006) aspek-aspek dalam pengelolaan kelas yaitu:

a. Keterlibatan siswa secara aktif

Siswa yang aktif belajar hanya mempunyai kesempatan yang sedikit untuk tidak mengerjakan tugas atau bertingkah laku yang menyimpang.

b. Sedikit gangguan

Guru tidak berhenti mengajar maka siswa juga tidak berhenti belajar. Kondisi di kelas selalu saja ada yang namanya gangguan dan kekacauan seperti berbicara dengan teman, tertawa bermain-main dan guru harus segera menghentikan gangguan sebelum mengganggu seluruh kelas dan masalah kedisiplinan terjadi hanya ketika strategi pencegahan gagal dan guru tidak cukup berada di tempat.

c. Penggunaan waktu belajar yang efisien.

Pendekatan yang efisien untuk memaksimalkan penggunaan waktu meliputi prosedur sebagai berikut yaitu ketika siswa masuk kelas, mereka akan membaca tugas yang telah ditulis guru di papan tulis atau membaca tugas yang diletakkan guru dibangku siswa.

Sifat-sifat guru yang diharapkan oleh siswa yaitu:

1. Sikap tenang.

Guru yang tenang membuat siswa tidak stress. Guru yang dapat mengontrol dirinya akan memberikan kesan pada siswa bahwa guru mempunyai cadangan yang tidak habis-habisnya, sehingga tidak ada gunanya melawan guru tersebut.

2. Teguh dan tegas.

Siswa menaruh hormat terhadap guru yang teguh pendirian dan tegas bertindak. Siswa akan berpikir lebih dahulu untuk melakukan tindakan yang menyimpang jika menghadapi guru yang tegas. 
3. Rajin dan kuat.

Guru yang rajin dan semangat untuk bekerja akan menjalar pada siswa-siswanya. Siswa tidak akan ragu-ragu dalam melakukan tugas karena contoh yang baik dari guru yang rajin.

4. Gembira.

Guru yang bergembira dan bersemangat untuk bekerja akan menghasilkan kerja yang memuaskan. Semua masalah dihadapi dengan gembira, karena tahu bahwa semua masalah pasti ada jalan keluarnya.

5. Simpati.

Simpati yang artinya lebih dalam, yaitu simpati yang betul-betul wajar, secara jujur guru ingin mendapatkan pandangan dari sudut siswa, menghargai masalahnya, masuk ke dalam kehidupan siswa, dan membantu siswa berarti juga membantu dirinya sendiri.

6. Hangat.

Kebutuhan akan kehangatan bukanlah sesuatu yang terlalu emosional. Guru yang lembut dan menghargai siswa akan tampak ketika berhubungan dengan siswa.

7. Waspada.

Guru yang mempunyai ketajaman mata, telinga, dan persepsi yang terlatih, hanya sedikit terpengaruh jika terjadi sesuatu yang hilang dari perhatian.

8. Terbuka dan adil.

Siswa akan memaafkan apa pun yang terjadi pada guru, kecuali ketidakterbukaan atau sikap memihak. Siswa akan lebih bersedia menerima hukuman atau pekerjaan yang sulit, jika mereka tahu dan percaya bahwa guru memberlakukan mereka dengan adil. Seorang guru yang menghukum siswa dengan keras yang tidak sesuai dengan situasi dapat menciptakan kebencian.

9. Sikap terhadap kesalahan.

Guru sebaiknya lebih toleran terhadap kesalahan yang dibuat oleh siswa. Seorang siswa yang membuat kesalahan karena menjawab terlalu cepat dapat dibantu untuk lebih pelan dan mengatur jawaban sebelum menjawab. Seorang siswa yang sangat berhati-hati untuk menghindari terjadinya kesalahan, dapat didorong untuk tidak takut menghadapi kesalahan. Kesalahan adalah manusiawi. 
10. Aturan, sistem, dan kerapian.

Nilai-nilai aturan, sistem, dan kerapian yang tercermin pada guru akan tercermin pula pada siswa. Jika segalanya sesuai dengan aturan yang berlaku, maka kecil kemungkinan terjadi penyimpangan tingkah laku di kelas.

\section{Kompeten.}

Guru yang kompeten dalam mengajar berpengaruh besar pada tugas-tugas akademik siswa. Kompeten juga termasuk kemampuan merencanakan pelajaran secara hati-hati sebelum masuk kelas, mengorganisasikan bahan, membuat diagram. Guru di satu pihak menangani pelajaran secara kompeten, di lain pihak menentramkan siswa dan membantu siswa menguasai pelajaran.

12. Kesarjanaan.

Kesarjanaan sendiri tidak akan mendisiplinkan kelas, tetapi guru yang menyandang gelar sarjana membuat siswa hormat terhadap guru. Hormat terhadap guru merupakan dasar yang baik dalam memupuk kontrol kelas secara keseluruhan.

\section{METODE}

\section{Partisipan}

Populasi dalam penelitian ini adalah seluruh siswa-siswi SMK Pabaku yang berjumlah 248 orang. Pemilihan sampel adalah menggunakan tekniks simple random sampling yaitu dengan memilih sampel berdasarkan pertimbangan-pertimbangan peneliti yang disesuaikan dengan tujuan penelitian.

\section{Desain}

Untuk mengetahui Hubungan persepsi siswa dengan kedisiplinan guru dalam mengelola kelas, dengan menggunakan pendekatan kuantitatif. Penelitian ini dilaksanakan dengan membagikan skala kedisiplinan dan persepsi siswa dengan pengelolaan kelas pada siswa-siswi SMK Pabaku 


\section{Prosedur}

Pengumpulan data penelitian menggunakan pembagian skala, yaitu skala kedisiplinan dan persepsi siswa terhadap pengelolaan kelas yang disusun dalam bentuk pernyataan dengan menggunakan skala likert. Pengujian skala dilakukan berdasarkan pengujian Uji Validitas dan Uji Reliabilitas.

\section{Teknik Analisis}

Analisis data menggunakan korelasi Product Moment untuk mengetahui bagaimana hubungan antara variable kedisiplinan dengan variable persepsi siswa terhadap pengelolaan kelas. Sebelum dilakukan uji ini, terlebih dahulu dilakukan uji asumsi, yaitu uji normalitas sebaran dan uji linearitas hubungan, sebagai prasyarat sebelum dilakukan uji korelasi.

\section{ANALISIS DAN HASIL}

Secara umum, penelitian ini bertujuan untuk mengetahui Hubungan persepsi siswa dengan kedisiplinan guru dalam mengelola kelas di SMK Pabaku.

Hasil analisis berdasarkan data primer dari 155 sampel untuk melihat hubungan antara kedua variabel. Sebelumnya dilakukan uji normalitas dan linearitas.

Uji normalitas dilakukan agar dapat mengetahui apakah setiap variabel penelitian telah menyebar secara normal. Uji normalitas sebaran menggunakan uji Kolmogorov Smirnov. Normalitas variable Kedisiplinan dan persepsi terhadap pengelolahan kelas maka dapat dilihat pada Tabel 1 seperti di bawah ini:

Tabel 1. Hasil Uji Normalitas

\begin{tabular}{|l|l|l|l|l|l|}
\hline Variabel & SD & K-SZ & Sig. & P & Keterangan \\
\hline $\begin{array}{l}\text { Persepsi Siswa Terhadap } \\
\text { Pengelolaan Kelas }\end{array}$ & 11,624 & 0,656 & 0,514 & $\mathrm{P}>0,05$ & Sebaran Normal \\
\hline Kedisiplinan & 12,663 & 0,750 & 0,624 & $\mathrm{P}>0,05$ & Sebaran Normal \\
\hline
\end{tabular}


Data dikatakan berdistribusi normal jika $\mathrm{p}>0,05$. Dari hasil tes Kolmogorov Smirnov maka dapat disimpulkan variable kedisiplinan menunjukkan nilai K-SZ sebesar 0,750 dengan Sig sebesar 0,624 ( $\mathrm{p}>0,05)$, artinya sebaran skor kedisiplinan mengikuti distribusi normal dan variable persepsi terhadap pengelolaan kelas menunjukkan nilai K-SZ sebesar 0,656 dengan Sig sebesar 0,514 ( $\mathrm{p}>0.05)$, artinya sebaran skor persepsi siswa terhadap pengelolaan kelas mengikuti distribusi normal.

Uji linearitas digunakan untuk mengetahui apakah distribusi data penelitian yaitu variabel kedisiplinan dan persepsi siswa terhadap pengelolaan kelas memiliki hubungan linear Uji F (Anova). Variabel kedisiplinan dan persepsi siswa terhadap pengelolaan kelas dikatakan memiliki hubungan linear jika $\mathrm{p}<0,05$. Hasil uji linearitas dapat dilihat pada Tabel 2.

Tabel 2. Hasil Uji Linearitas Hubungan

\begin{tabular}{|l|l|l|l|}
\hline Variabel & F & Sig. & Keterangan \\
\hline $\begin{array}{l}\text { Kedisiplinan } \\
\text { Persepsi Terhadap Pengelolaan Kelas }\end{array}$ & 134,924 & 0,000 & Linear \\
\hline
\end{tabular}

Berdasarkan Tabel 2 dapat dikatakan bahwa variable kedisiplinan dan persepsi siswa terhadap pengelolaan kelas memiliki hubungan linear. Hal ini terlihat dari nilai p yang diperoleh yaitu 0,000 maka $\mathrm{p}<0,05$ sehingga dapat disimpulkan bahwa kedua variabel memiliki hubungan linear dan telah memenuhi syarat untuk dilakukan analisa korelasi Product Moment.

Hipotesis dalam penelitian ini adalah adanya hubungan antara persepsi siswa dalam pengelolaan kelas terhadap kedisiplinan. Berdasarkan tujuan penelitian maka dilakukan uji Pearson Correlation. Hasil uji statistik dapat dilihat pada Tabel 3.

Tabel 3. Korelasi Antara Kedisiplinan dengan Persepsi Siswa terhadap Pengelolaan Kelas.

\begin{tabular}{|l|l|l|}
\hline Analisis & Pearson Correlation & Signifikasi (p) \\
\hline Korelasi & 0,605 & 0,000 \\
\hline
\end{tabular}


Berdasarkan hasil analisis korelasi antara Kedisiplinan dengan persepsi siswa terhadap pengelolaan kelas, diperoleh koefisien korelasi product moment sebesar 0,605 dengan p sebesar $0,000$ ( $\mathrm{p}<0,05)$. Hal ini menunjukkan bahwa adanya korelasi antar kedisiplinan dengan persepsi siswa terhadap pengelolaan kelas (Priyatno, 2011).

Berdasarkan hasil perhitungan tersebut, maka hipotesis yang diajukan dalam penelitian ini yang menunjukkan ada hubungan antara kedisiplinan dengan persepsi siswa terhadap pengelolaan kelas pada siswa-siswi SMK Pabaku diterima.

\section{DISKUSI}

Hasil penelitian pada 155 siswa-siswi SMK Pabaku yang menjadi subjek penelitian diperoleh hasil bahwa ada hubungan yang signifikan antara kedisiplinan dengan persepsi siswa terhadap pengelolaan kelas dengan koefisien korelasi product moment sebesar $\mathrm{r}=0,605$; nilai $\mathrm{p}$ sebesar 0,000; artinya semakin tinggi skor persepsi siswa terhadap pengelolaan kelas, maka semakin tinggi kedisiplinan.

Melalui penelitian ini diperoleh koefisien determinasi $\left(r^{2}\right)$ sebesar 0,591. Berdasarkan hasil tersebut, dapat disimpulkan bahwa 59.1 persen kedisiplinan dipengaruhi oleh persepsi siswa dan selebihnya 49,9 persen dipengaruhi oleh faktor lain. Faktor lain yang tidak diteliti seperti teman sebaya,pola asuh orang tua dan lain sebagainya.

Dengan demikian dapat ditarik kesimpulan bahwa semakin tinggi skor persepsi siswa terhadap pengelolaan kelas, maka semakin tinggi pula kedisiplinan. Sebaliknya semakin rendah skor persepsi siswa terhadap pengelolaan kelas, maka semakin rendah pula kedisiplinan.

\section{SIMPULAN DAN SARAN}

\section{A. Kesimpulan}

Berdasarkan hasil-hasil yang telah diperoleh dalam penelitian ini, maka dapat disimpulkan bahwa ada hubungan yang signifikan antara kedisiplinan dengan persepsi siswa 
Psikologi Prima

terhadap pengelolaan kelas pada siswa-siswi SMK Pabaku, dengan korelasi Product Moment (r) sebesar 0,605 dan p sebesar 0,000 ( $\mathrm{p}<0,05)$; artinya semakin tinggi skor persepsi siswa terhadap pengelolaan kelas, maka semakin tinggi pula kedisiplinan. Sebaliknya semakin rendah skor persepsi siswa terhadap pengelolaan kelas, maka semakin rendah pula kedisiplinan.

Hasil penelitian ini menunjukkan bahwa sumbangan yang diberikan variable kedisiplinan terhadap persepsi siswa terhadap pengelolaan kelas adalah sebesar 59,1 persen, sisanya 49.9 persen dipengaruhi oleh faktor lain yang tidak diteliti, seperti: pengaruh teman sebaya, pola asuh orang tua.

\section{B. Saran}

Berdasarkan hasil penelitian maka terdapat beberapa saran yang diharapkan dapat berguna.

1. Bagi siswa diharapkan meningkatkan kedisiplinan dalam proses belajar mengajar, dan tepat waktu dalam mengumpulkan tugas dan masuk kelas dalam upaya meningkatkan nilai akademik.

2. Bagi sekolah agar memberikan pelatihan pada guru dalam mengelola kelas dan reward jika guru dapat mengelolah kelas dengan baik.

3. Bagi guru agar meningkatkan skill dalam mengelola kelas agar dapat meningkatkan kedisiplinan dan meningkatkan prestasi siswa.

\section{DAFTAR PUSTAKA}

Atkinson, Rita L. Atkinson, Richard C. Hilgard, E. R. (2002). Pengantar Psikologi. Batam: Interaksara.

Chaplin, J. P. (2008). Kamus Psikologi Lengkap. Jakarta: PT Raja Grafindo. 
Psikologi Prima

Djiwandono, S, E, W. (2006). Psikologi Pendidikan. Jakarta: PT Gramedia Widiasarana.

Ekosiswoyo, R . Rachman, M. (2000). Manajemen Kelas. Semarang: IKIP Semarang Press.

Ormrod, J. E. (2011). Educational Psychology. Boston: Pearson.

Santrock, J. W. (2008). Psikologi Pendidikan. Jakarta: Erlangga.

Slavin, R. E. (2011). Psikologi Pendidikan Teori Dan Praktik. Jakarta: PT Indeks.

Suryabrata, S. (2006). Psikologi Pendidikan. Jakarta: PT Raja Grafindo Persada.

Tu'u, T. (2004). Peran Disiplin pada Perilaku dan Prestasi Siswa. Jakarta: Grasindo. 